\title{
AZYUMARDI AZRA'S THOUGHT ON MULTICULTURAL EDUCATION
}

\author{
Muh. Idris \\ Institut Agama Islam Negeri Manado \\ J1. Dr. SH. Sarundajang Kawasan Ringroad I Manado, Sulawesi Utara, 95000 \\ e-mail: idristunru02@gmail.com
}

\begin{abstract}
Islamic religious education is often accused of advocating religious fanaticism and ideology of truth. The condition is resulted from relative detachment of religious education from social reality. As such, religious education fails to strengthen the awareness of religious plurality in the society. This paper is the result of a Content Analysis research on Azyumardi Azra's thoughts on multicultural education. It is found that according to Azyumardi Azra, multicultural education is an education of and for socio-cultural diversity aiming at strengthening the Indonesian unity amid its very diverse population. Unity in Diversity is one of the four pillars of Indonesian nationhood namely the Pancasila, NKRI, 1945 Constitution, and Unity in Diversity.
\end{abstract}

\begin{abstract}
Abstrak: Pendidikan agama yang selama ini dijalankan sering dikritik karena dianggap menimbulkan fanatisme keberagamaan dan melahirkan ideologi kebenaran karena praktik pendidikan agama kurang menyentuh aspek realitas sosial. Pendidikan agama kurang menumbuhkan kesadaran positif tentang realitas plural kehidupan agama masyarakat. Tulisan ini menganalisis pemikiran Azyumardi Azra tentang pendidikan multikultural. Dengan menggunakan analisis isi penelitian ini menemukan bahwa pendidikan multikultural dalam pandangan Azyumardi Azra adalah pendidikan untuk/tentang keragaman kebudayaan masyarakat Indonesia tentang pembentukan keikaan di tengah kebhinnekaan. Konsep pendidikan multikultural Azyumardi Azra ini berangkat dari realitas masyarakat Indonesia dalam rangka memperkuat kembali (revitalisasi) empat pilar wawasan kebangsaan yaitu Pancasila, NKRI, UUD 1945, dan Bhinneka Tunggal Ika.
\end{abstract}

Keywords: education, multiculturalism, Azyumardi Azra, fanatism 


\section{Introduction}

In recent years, criticism of religious education in both public education institutions and in religious education institutions has much attention in Indonesia. One of the most serious figures to carry out such criticism is Azyumardi Azra. He is an intellectual who develops inclusive and pluralist progressive Islamic thought, both through universities, discussion forums, seminars, conferences and papers in the form of articles, journals and books. According to him, religious education was not successful in shaping religious attitudes that reflected 'IMTAK' (faith and piety); also seen as less successful in fostering a tolerant attitude in dealing with differences between religious communities both intra and between religions.

In his writings he repeatedly criticized the intolerant model of religious education which is developing in Indonesia while presenting the concept of multicultural education as an educational concept that must be held by educational institutions in an effort to strengthen (revitalize) the concept of nationalism. Moreover, the Indonesian nation is now seen to be disoriented in various fields of life. Even more complicated, Indonesia consists of ethnic communities that live on different levels of culture or civilization, which contain cultural gaps.

As an Indonesian Muslim intellectual who has an important role in the development of Islamic thought in Indonesia, he formulates multicultural education that is appropriate to the conditions of Indonesian society who are experiencing disorientation, in various fields of life, and living at different cultural levels. Some people still live in a pre-agrarian culture, most in an agrarian culture, some in an industrial culture, and a few have been in IT culture. In this aspect the attractiveness of Azyumardi Azra's thinking about multicultural education. In which he formulated multicultural education to strengthen Unity in Diversity as education for the cultural diversity of Indonesian society in the past and today that is undergoing demographic and sociocultural changes. Mutual understanding and understanding between various diverse cultural entities can be grown through this kind of education with their respective proponent.

This paper tries to find a common thread that unites the thoughts of Azyumardi Azra that have been separated in a number of books, articles, journals, and papers in various discussions and seminars. So, the results of this study can be an important contribution in formulating multicultural education in educational institutions.

\section{Methodology}

This type of research is a library research with a qualitative approach. ${ }^{1}$ The type of

${ }^{1}$ Sugiyono, Metode Penelitian Pendidikan Pendekatan Kuantitatif, Kualitatif, dan R\&D (Bandung: Alfabeta, 2011), p. 15. 
data used is in the form of written documents, whether of a public or private nature. This type of data is in the form of interpretations, and statements made by Azyumardi Azra in the books, articles, journals and papers about multicultural education. Analysis of the data used is content analysis ${ }^{2}$ sourced from the results of library data exploration. Content analysis technique is research that is in-depth discussion of the issue of written or printed information in the mass media. In analyzing the data with the content of this analysis the data taken in the form of the works of Azyumardi Azra are then simplified so that data collected that has the same theme is multicultural education. From the data collected, a depth discussion of the Azyumardi Azra's concept of multicultural education can be obtained so that data can connect the meaning of the text with the conclusions of the study.

\section{Results and Discussion}

\section{Azyumardy Azras's Biography}

Azyumardi Azra was born in Lubuk Alung, West Sumatra, in March 4, 1955. After completing his studies at Tarbiyah Faculty of IAIN Jakarta in 1982, in 1986 he obtained a Fullbright Scholarship to continue his studies at Columbia University, New York. The MA degree was obtained in 1988 from the Middle East Languages and Culture Department, Colombia University. Obtained Colombia University President Fellowship, continued doctoral program at the Department of History, Colombia University. From this Department obtained a second MA in 1989 and M.Phil. in 1990. While a Ph.D. obtained from the Department of History of Colombia University in 1992 with a dissertation entitled "The Transmission of Islamic Reformism to Indonesia: Networks of Middle Eastern and Malay Indonesian Ulama in the Seventeenth and Eighteenth Centuries. ${ }^{3}$

Since 1982 Azyumardi Azra has been a lecturer at IAIN Syarif Hidayatullah Jakarta and a number of Postgraduate Programs in Indonesia. Becoming Professor of History at the Adab Faculty since 1997. Becoming Director of the Postgraduate Program at the State Islamic University (UIN) Syarif Hidayatullah Jakarta since January 2007. He served as Deputy for People's Welfare at the Vice President's Secretariat of the Republic of Indonesia (April 2007-20 October 2009). Previously, IAIN/UIN Chancellor Syarif Hidayatullah for two periods (IAIN, 1998-2002 and UIN, 2002-2006). ${ }^{4}$

${ }^{2}$ Bruce A. Chadwick et al., Metode Penelitian Ilmu Pengetahuan Sosial (Semarang: IKIP Press, 1991), p. 270.

${ }^{3}$ Azyumardi Azra, Jaringan Ulma Timur Tengah dan Kepulauan Nusantara Abad XVII dan XVIII Melacak Akar-Akar Pembaruan Pemikiran Islam di Indonesia (Bandung: Mizan, 1994); Azyumardi Azra, Pendidikan Islam Tradisi dan Modernisasi Menuju Milenium Baru (Ciputat: Logos Wacana Ilmu, 1999).

${ }^{4}$ Azyumardi Azra, Pendidikan Islam Tradisi dan Modernisasi di Tengah Tantangan Milenium III (Jakarta: Prenada Media Group, 2012), p. 323. 
In the field of science and research, Azyumardi Azra is a member of the Indonesian Academy of Sciences (AIPI, 2005); National Research Council member (DRN, 2005). Also a member of the Southeast Asian Religion Exchange Program (SEASREP, Tokyo, 1991-2001); Asian Research Foundation-Asian Muslim Action Network (ARFAMAN, Bangkok, 2004); The Habibi Center Scholarship (2005); Ford Foundation International Fellowship Program (IFP-IIEF, 2006); Asian Scholarship Foundation (ASF, Bangkok, 2006); Asian Public Intellectual (API), the Nippon Foundation (Tokyo, 2007) member of the AMINEF-Fulbright Senior Fellow Program Selection Committee (2008).

In addition, Azyumardi Azra was a member of the Founding Council for Partnerships for Governance Reform in Indonesia (2004); United Nations Democracy Fund Advisory Board (UNDEF, New York 2006); International IDEA (Institute for Democracy and Electoral Assistance), Stockholm (2007-present); Institute of Global Ethics and Religion, USA (2004present); LibforAll, USA (2006-present); The Center for the Study of Contemporary Islam (CSCI, University of Melbourne, 2005-2007); Tripatite Forum for Inter-Faith Cooperation (New York, 2006-present); member of the World Economic Forum's Global Agenda Council on The West-Islamic dialogue (Davos 2008-present).

Azyumardi Azra is also editor in chief of Studia Islamik: Indonesian Journal for Islamic Studies (Jakarta, 1994-present); Journal of Qur'anic Studies (SOAS, University of London, 2006-present); Journal of Ushuluddin (Malaya University, Kuala Lumpur, 2006-present); Journal of History (Malaya University, Kuala Lumpur, 2005-now); The Australian Journal of Asian Law (Sydney, Australia, 2008-present); IAIS Journal of Civilization Studies (International Institute of Advanced Studies, Kuala Lumpur, 2008present); Journal of the Royal Asiatic Society (JRAS, London, 2009-present); Journal of Islamic Studies (Oxford Center for Islamic Studies, 2010-present; and Academic Journal (Universiti Kebangsaan Malaysia, 2010-present).

Azyumardi Azra has published more than 21 books, the last being Indonesia, Islam and Democracy: Dynamic in a Global Context (Jakarta \& Singapore, TAF, ICIP, EquinoxSolstice, 2006); Islam in the Indonesian World: An Account of Institutional Development (Mizan International: 2007); (co-contributing editor), Islam Beyond Conflict: Indonesian Islam and Western Political Theory (London: Ashgate: 2008); Varieties of Religious Authority: "Changes and Challenges in 20th Century Indonesian Islam (Singapore: ISEAS, 2010). More than 30 articles in English have been published in various books and journals at the international level.

In 2005 Azyumardi Azra won The Asia Foundation Award in the 50th anniversary of TAF for its important role in the modernization of Islamic education; in commemoration of the Republic of Indonesia's Independence Day, on August 15, 2005 was awarded the Bintang Mahaputra Utama RI for its contribution in the development of moderate Islam; and in September 2010, he was awarded the CBE (Commander of the Order of the British 
Empire) title from Queen Elizabeth, United Kingdom for his services in interfaith relations and civilization. ${ }^{5}$

Azyumardi Azra is known as the golden star of UIN Jakarta. This can be seen from its success in lifting dignity of UIN Jakarta in the world of education in Indonesia and abroad. With his capacity and scientific integration, he is able to become the most important icon for the development and progress of UIN Jakarta so that he appears as one of the most favorite universities in Indonesia and even in Southeast Asia. ${ }^{6}$

\section{Azyumardy Azras's Concept of Multicultural Education}

Azyumardi Azra is one of the famous figures in this era. Seeing the backwardness of Islamic education that is far behind from general education, he then came up with his ideas in the form of reforming the religious education system. One renewal of the religious education system is multicultural education.

Azyumardi Azra believes that multicultural education is very much needed in public schools. This is due to religious education in public schools often received sharp criticism from the community. Religious education is seen as unsuccessful in forming religious attitudes and attitudes that reflect faith and piety; It is also seen as less successful in developing a tolerant attitude in dealing with differences between religious communities both intra and between religions. ${ }^{7}$

Educational institutions, including Islamic educational institutions, until now day are considered to still not have significant strength when compared with other forces, such as business and political forces. Allegedly, that the cultural centers today are not in the academic world, but in the business and political world. In such a setting Islamic educational institutions are threatened with subordination. Indonesia is known as a country that occupies the largest position of its Muslim population. But the potential of the majority of Muslims has not guaranteed its social role. This is certainly related to the function and target of the education developed, and the Islamic education model that is in line with the demands of the development and needs of the community today. ${ }^{8}$

The religious education model that has been implemented, in fact often leads to

\footnotetext{
5 "Biografi Singkat: Azyumardi Azra," in https://cakrawalazen.wordpress.com/2018/ 01/30/biografi-singkat-azyumardi-azra, accessed January 20, 2020.

${ }^{6}$ Siti Napsiyah Ariefuzzaman, "Prof. Dr. Azyumardi Azra, MA: Paradigma Baru Pendidikan Islam di Indonesia," in Chairul Fuad Yusuf and Ahmad Syahid (ed.), Pemikir Pendidikan Islam: Biografi Sosial Intelektual (Jakarta: Pena Citasatria, 2007), p. 46.

${ }^{7}$ Azyumardi Azra, Dari Harvard Hingga Mekkah (Jakarta: Penerbit Republika, 2005), p. 49.

${ }^{8}$ M. Zainuddin (ed.), Memadu Sains dan Agama Menuju Universitas Islam Masa Depan (Malang: Bayu Media Publishing, 2004), p. v.
} 
religious fanaticism and the creation of an ideology of truth claims. ${ }^{9}$ This is because the practice of religious education does not touch aspects of social reality, which is actually also a claim of religion. ${ }^{10}$ Religious education in schools does not foster a positive awareness of the plural reality of community religious life, both internally in the life of religion itself and externally in relation to other religions. ${ }^{11}$

As a system, Islamic education has become a sub-system of national education because historically, Islamic education has become an integral part of Indonesian history. In this context, the role of Islamic education cannot be ignored. Therefore, education needs to be understood not only for the nation, but also contain the aim of human personality development. ${ }^{12}$

The survival of a nation depends on its educated citizens. Education is not just teaching or transferring knowledge, or merely developing intellectual aspects, but also to develop students' character, morals, values and culture. ${ }^{13}$ Developing the nature and human potential towards the formation of a whole human being are the goals achieved by Education. ${ }^{14}$ Education is not only works as a knowledge transfer, but also as a driver for the development of noble values which are the basis for the development of good manner/good character. Good character includes honest, fair, democratic, disciplined and tolerant attitudes. ${ }^{15}$ The main problem faced by religious educators and social activists in the pluralistic and multicultural eras is how each religious tradition can continue to preserve, maintain, perpetuate, transfer and inherit the beliefs and traditions that are believed to be absolute truths, but at the same it is also fully aware of the existence of other religious tradition groups who also do the same. In addition to strengthening self and group identities, what efforts do religious social educators make in each tradition to also maintain togetherness and social cohesion? If it is recognized the need for this, then the implications and consequences of the methods, material choices, and education and teaching techniques of religion will be presented to the plural, open-plural society as it is today. ${ }^{16}$

\section{p. 89.}

${ }^{9}$ Syamsul Ma'arif, Pendidikan Pluralisme di Indonesia (Yogyakarta: Logung Pustaka, 2005),

${ }^{10}$ Ahmad Fuadi Fanani, Islam Mazhab Kritis Menggagas Keberagamaan Liberatif (Jakarta: Kompas, 2004), p. 17.

${ }^{11}$ Mahmud Arif, Pendidikan Islam Transformatif (Yogyakarta: LKiS, 2008), p. 215.

${ }^{12}$ Moch. Tolchah, "The Relation Between Nusantara Islam and Islamic Education in Comtemporay Indonesia," in Al-Ulum, Vo. 16, No. 1, Juni 2016, p. 7.

${ }^{13}$ Dodi Nandika, Pendidikan di Indonesia di Tengah Gelombang Perubahan (Jakarta: Pustaka LP3ES Indonesia, 2007), p. 15.

${ }^{14}$ Muh. Idris, "Konsep Pendidikan Humanis dalam Pengembangan Pendidikan Islam" in Miqot: Jurnal Ilmu-ilmu Keislaman, Vol. XXXVIII, No. 2, Juli-Desember 2014, p. 425.

${ }^{15}$ Sulistyowati Irianto (ed.), Otonomi Perguruan Tinggi Suatu Keniscayaan (Jakarta: Yayasan Pustaka Obor Indonesia, 2003), p. 53-54.

${ }^{16}$ M. Amin Abdullah, Pendidikan Agama Era Multikultural - Multi Religius (Jakarta: PSAP, 2005), p. 2-3. 
Education in Indonesia is characterized by a structural dichotomy, in which two schooling systems exist concurrently. The first system consists of general school, which are administered by Ministry of Education and Culture (MoEC), while the second is comprised of pesantren, madrasah, and other religious schools, which are under the administration of Ministry of Religious Affairs (MORA). ${ }^{17}$

The Education Model that is suitable for Indonesia's future must of course be explored from the sociological, anthropological, and theological aspects of its people. The Indonesian nation is a unique nation; is a collection of various ethnic and religious groups who differ from one another. Then cultural and religious diversity must be utilized as well as possible to help each other, compete to make virtues, and create goodness and harmony of life. Azyumardi Azra stated that diversity, or diversity or multiculturalism, is one of the main realities experienced by society and culture in the past, even more so in the present and future. Multiculturalism can be simply understood as recognition, a country or society is diverse and diverse. In contrast, no country contains only a single national culture.

Diversity should not be interpreted singly. Furthermore, a commitment to recognize diversity as one of the main characteristics and characteristics of societies and nationstates does not mean dislocation, cultural relativism, social disruption or prolonged conflict in every community, community and ethnic and racial group. Because, at the same time there are also various symbols, values, structures and institutions in a common life that bind the various earlier diversity. ${ }^{18}$

All of this, and more specifically, institutions, structures, and even patterns of behavior also have a particular focus on collaboration, mediation and negotiation to resolve differences. Thus, they have the potential to resolve conflicts that can arise and develop at any time. All of these symbols, values, structures and institutions also strongly emphasize shared life, mutual support and respect for each other in a variety of personal and communal rights and obligations, and furthermore national society.

At this stage, commitment to certain values cannot be seen as related only to personal and social exclusivism, or to cultural superiority, but also to humanity. This framework also includes humanity commitment and cohesion through tolerance, mutual respect for personal and communal rights. Humans, when confronted with various symbols, doctrines, principles and patterns of behavior, express and idealize commitment to humanity both personally and communally — and to the culture it produces.

In this context, multiculturalism can also be understood as a belief in normality and

${ }^{17}$ Raihani, "Islamic Education and the Multicultural Society: Description of Education for Cultural Diversity in Two Islamic Schools in Indonesia," in Jurnal JISCA, Vol. 03, No. 02, Des 2014, p. 2.

${ }^{18}$ Azyumardi Azra, "Revitalisasi Wawawasan Kebangsaan Melalui Pendidikan Multikultural," in Jurnal Ledalero, Vol. 18. No.2, Desember 2019, p. 189-190. 
acceptance of diversity. This worldview of multiculturalism can be a starting point and foundation for civilized citizenship. Here, multiculturalism is the cultural basis for citizenship, citizenship and education. ${ }^{19}$

The formation of a healthy Indonesian multicultural society cannot be taken for granted or trial and error, on the contrary it must be pursued in systematic, programmatic, integrated, and continuous way. One of the most strategic steps in this regard is through multicultural education organized by tertiary institutions, both formal and informal and even informal in the wider community. ${ }^{20}$

At present multicultural education is very significantly developed by the people of Indonesia. Multicultural education is an educational model that is expected to contribute to the creation of peace and efforts to overcome conflicts that have been rife lately. Because the basic value of this education is the planting and grounding of the values of tolerance, empathy, sympathy, social solidarity, respect for diversity and differences of opinion and other attitudes that uphold humanity.

In multicultural education, discrimination is the main problem that becomes the background of the importance of implementing the education strategy. It is hoped that by implementing this educational strategy, the future generations will become the generation that always upholds justice, democracy and humanism. ${ }^{21}$ The focus is no longer directed solely on social, dominant or mainstream social groups, and religion. Such focus has been a pressure on intercultural education that emphasizes increasing understanding and tolerance of individuals who come from minority groups to the dominant mainstream culture, which in turn can make people from minority groups integrated into the mainstream society. Intercultural education like this ultimately leads to not only ignorance of minority cultural values, but even tends to preserve racist and discriminatory social and cultural prejudices. And from this framework, multicultural education is actually a caring and willing attitude to understand, and politics of recognition of minority groups. ${ }^{22}$

In this context multicultural education sees society more broadly. Based on the basic view of indifference and unrecognizing attitudes rooted not only from racial structural inequality, the multicultural education paradigm includes subjects regarding injustice, poverty, oppression, and underdevelopment of minority groups in various fields; social, cultural, economic, educational and others. This paradigm in turn encourages the growth

${ }^{19}$ Ibid., p.190.

${ }^{20}$ Azyumardi Azra, "Pendidikan Agama: Membangun Multikulturalisme Indonesia," in Zakiyuddin Baidhawi, Pendidikan Agama Berwawasan Multikultural (Jakarta: Penerbit Erlangga, 2003), p. vii.

${ }^{21}$ Yaqqin, Pendidikan Multikultural, p. 23.

${ }^{22}$ Azra, "Pendidikan Agama: Membangun Multikulturalisme Indonesia," p. ix.

${ }^{23} \mathrm{Ibid}$. 
of studies on ethnic studies, to then find its place in the education curriculum from the elementary level to the tertiary level. ${ }^{23}$

It is a fact that cannot be denied is that the Indonesian nations consist of various ethnic groups, cultures, religions and others, so that Indonesian countries can simply be called multicultural societies. But on the other hand the multicultural reality is faced with an urgent need to reconstruct Indonesia's national culture which can become an integrating force that binds all ethnic and cultural diversity. ${ }^{24}$ Therefore, multicultural education necessary carried out by educational institutions.

Simply put, multicultural education is defined by education for / about the cultural diversity of the Indonesian people in the past and today who are experiencing demographic and socio-cultural changes. Through this kind of education one can grow mutual understanding and mutual understanding among various diverse cultural entities complete with their respective supporters. ${ }^{25}$

Multicultural education looks at society more broadly. Based on the basic view that indifference and non-recognition attitudes are rooted not only from racial structural inequalities, the multicultural education paradigm includes subjects regarding injustice, poverty, oppression and underdevelopment of minority groups in various fields; social, cultural, economic, educational, and others. This paradigm in turn encourages the growth of studies on ethnic studies, to then find its place in the education curriculum from the elementary level to tertiary education. The core purpose of the discussion on all of these subjects is to achieve empowerment for minority and disadvantaged groups. ${ }^{26}$

The term multicultural education can be used at both descriptive and normative levels, which describe issues and educational problems relating to multicultural societies. Furthermore it also includes an understanding of the consideration of policies and strategies for education for students in multicultural societies. In this descriptive and normative context, the multicultural education curriculum must include subjects such as; tolerance; themes about ethno-cultural, and religious differences; danger of discrimination; conflict resolution and mediation; HAM; democracy and plurality; universal humanity, and other relevant subjects. ${ }^{27}$

The formulation and implementation of multicultural education in Indonesia still requires serious and special discussion. This is not only because it involves the issue of the content of multicultural education itself, but also about the strategy to be adopted;

24 "Pendidikan Multikutural Membangun Kembali Indonesia Bhinneka Tunggal Ika," in https://wewenimas.wordpress.com, accesed 20 January 2020.

${ }^{25}$ Azra, "Revitalisasi Wawawasan Kebangsaan," p. 298.

${ }^{26}$ Azra, "Revitalisasi Wawasan Kebangsaan: Pancasila, NKRI, UUD 1945 dan Bhinneka Tunggal Ika Pendekatan Pendidikan Multikultural" (Makalah "Penguatan Nilai Kebangsaan Guna Merajut Kebhinnekaan dalam Rangka Ketahanana nasional" PPRA Lemhanas LVI 2017).

${ }^{27} \mathrm{Ibid}$. 
whether for example in the form of separate, stand-alone, or otherwise integrated or integrated subjects. Apart from these issues and problems, it is clear that Indonesia's development now seems to require multicultural education, which is expected to make an important contribution to the formation of marriage in the midst of true diversity; not just slogans and jargon. And this, in turn, will strengthen the actualization of Pancasila as one of the main identities and identities in the life of the nation and state. ${ }^{28}$

Azyumardi Azra concept of multicultural education base on the reality or condition of the Indonesian people in order to strengthen (revitalize) the four pillars of national insight (Pancasila, NKRI, 1945 Constitution, and Unity in Diversity) and identity (Indonesian identity in the midst of the reality of ethnic diversity, religion, race, gender, customs and social traditions, especially since the nation of Indonesia today seems to be disoriented in various fields of life, even more complicated Indonesia consist of ethnic communities that live on different levels of culture or civilization, which contains cultural gaps.: Some of our nation's people still live in pre-agrarian culture, then most in agrarian culture, some in industrial culture, and a small part have entered digital IT culture. ${ }^{29}$

In order to strengthen Unity in Diversity, multicultural education is necessary. So Azyumardi Azra offers the concept of multicultural education with education for / about the cultural diversity of Indonesian society in the past and today that is undergoing demographic and socio-cultural changes. Through this kind of education one can grow mutual understanding and mutual understanding between various diverse cultural entities complete with their respective proponents. ${ }^{30}$

The formation of a healthy Indonesian multicultural society cannot be taken for granted or trial and error, on the contrary it must be pursued systematically, programmatically, integratedly, and continuously. One of the most strategic steps in this regard is through multicultural education organized by tertiary institutions, both formal and informal and even informal in the broad community. ${ }^{31}$

\section{Discussion}

The discourse on multicultural education is increasingly emerging along with the continuing flow of democratization in the life of the nation, which has implications for strengthening civil society and respect for human rights. Democracy which has become the nation's choice since the reform movement at the end of the 20th century became the spirit of community life in the nation and state, building unity and unity, building strength

\footnotetext{
${ }^{28}$ Azra, "Revitalisasi Wawawasan Kebangsaan," p. 200-201.

${ }^{29}$ Ibid., p. 183-184.

${ }^{30}$ Ibid., p. 198.

${ }^{31}$ Azyumardi Azra, Pendidikan Agama, p. vii.
} 
in diversity, and eliminating cultural, racial, linguistic and religious barriers for the benefit of the nation to future demanded to be increasingly competitive in the face of global competition. $^{32}$

Indonesia is a country that consists of various ethnic groups, cultures, ethnicities and religions so that Indonesia can simply be called a multicultural society. But on the other hand the multicultural reality is faced with an urgent need to reconstruct Indonesia's national culture which can become an integrating force that binds all ethnic and cultural diversity.

Therefore we need the attitude of each group to be willing to unite regardless of the cultural diversity they have. They all merged, so that in the end there was a process of "hydriding" which asked everyone/parties not to emphasize differences in their respective cultures. There is also no sort of coercion to become a culture. ${ }^{33}$

The main problem faced by educators and religious social activists in the pluralistic and multicultural eras is how each religious tradition can continue to preserve, preserve, perpetuate, transfer, and pass down the beliefs and traditions that are believed to be absolute truths, but at the moment the same is also fully aware of the existence of other religious tradition groups who also do the same. In addition to strengthening self and group identities, what efforts can religious social educators make in each tradition to also maintain togetherness, social cohesion, and shared integrity ${ }^{34}$

Education is an important factor in a country where the majority of the population is Muslim, to ensure that the Islamic religion with all its teachings is maintained and inherited from generation to generation in a good manner. ${ }^{35}$ Education basically builds civilization. This requires a long process that is accompanied by tenacity, perseverance, dedication, unyielding spirit, even sacrifice. Building education is creating a crater to cultivate human children to be a formidable successor to the future. ${ }^{36}$

Education is considered as a very precise starting point in raising awareness of tolerance and respect for other cultures or identities. This also means that education is a strategic medium to foster multicultural awareness in a pluralistic society. Namely awareness to build mutual togetherness and harmony in living in a society, nation and state.

${ }^{32}$ Dede Rosyada, "Pendidikan Multikultural di Indonesia Sebuah Pandangan Konsepsional," in Sosio Didaktika Social Science Education Journal, Vol.1 No.1 Juni 2014, p. 1-2.

${ }^{33}$ Najmuddin Ramly, Membangun Pendidikan yang Memberdayakan dan Mencerahkan (Jakarta: Penerbit Grafindo Khazanah Ilmu, 2005), p. xv.

${ }^{34}$ M. Amin Abdullah, Pendidikan Agama Era Multikultural - Multi Religius (Jakarta: PSAP, 2005), p. 3.

${ }^{35}$ Marzuki, et al., "Multicultural Education in Salaf Pesantren and Prevention of Religious Radicalisme in Indonesia," in Cakrawala Pendidikan, Vol. 39, No. 1, Februari 2020, p. 12.

${ }^{36}$ Muh. Idris, et al., "Peace Resolution in Education and Application on Information and Communication Technology," in International Journal of Advanced Science and Technology, Vol. 29, No. 6, 2020, p. 3353. 
Therefore, the development of Islamic education realistically must be synchronized with national education policies to free the nation from the crush of various problems. ${ }^{37}$ One form of education that is quite relevant is multicultural education. According to Clive Beck as quoted by Syamsul Ma'arif defines multicultural education with an educational method that teaches students about the ethnic culture they have, also teaches the existence of various traditional cultures. The urge to accept every ethnic difference in society shows the differences in religion, race and nationality. ${ }^{38}$

Multicultural education is a progressive approach to transforming education that completely exposes shortcomings, failures, and discriminatory practices in the education process. Multicultural education is based on the ideas of social justice and equal rights in education. Multicultural education is a commitment to facilitate learning experiences that enable each student to reach their full potential as students and as active individuals and have social sensitivity at the local, national and global levels. ${ }^{39}$ In the aspect of education, multicultural education then offers alternatives through implementation strategies and educational concepts based on the use of diversity in society, especially among students such as ethnicity, culture, language, religion, social status, gender and race. The most important goal of multicultural education is to increase the awareness of students to behave humanist, pluralist, and democratic in overcoming all the differences that exist in society. ${ }^{40}$

Multicultural Education is at least three things: in idea or concept; in educational reform movement, and a process. Multicultural Education incorporates the idea that all students - regenerless of their gender, social class, and ethnicity, racial, or cultural characteristicsshould have an equal opportunity to learn in school. ${ }^{41}$

In multicultural education, discrimination is the main problem that becomes the background of the importance of implementing the education strategy. It is hoped that by implementing this educational strategy the future generations will become the generation that always upholds justice, democracy and humanism. ${ }^{42}$

Sleeter \& Grant note that the primary approaches to multicultural education all

${ }^{37}$ A. Malik Fadjar, "Strategi Pengembangan Pendidikan Islam di Era Globalisasi," in M. Zainuddin and Muhammad In'am Esa (ed.), Horizon Baru Pengembangan Pendidikan Islam Upaya Merespon Dinamika Masyarakat Global (Malang: UIN Press, 2004), p. xxi-xxii. p. 8 .

${ }^{38}$ Syamsul Ma'arif, Pendidikan Pluralisme di Indonesia (Yogyakarta: Logung Pustaka, 2005),

${ }^{39}$ Melani Budianta, "Multikulturalisme dan Pendidikan Multikultural: Sebuah Gagasan Umum," in Tsaqafah, Vo. 1, No. 2, 2003.

${ }^{40}$ Ulfa Masamah and Mualimul Huda, "Multicultural Education and The Nationalistic Reality (Photograph The Role of Teachers in Building a Multicultural Awareness in Indonesia," in QIJIS: Qudus International Journal of Islamic Studies, Vol. 4, No. 1, Februari 2016, p. 73.

${ }^{41}$ James A Banks, and Cherry A. Mcgee Banks (ed.), Multicultural Education Issues and Perspective (n.d.: The United States of America, 2010), p. 3.

42 Yaqqin, Pendidikan Multikultural, p. 23. 
use the rhetoric and language of a pluralist style but are constrained by still being grounded in positivistic mainstream values and conditioned by deficiency theories for interpreting minority student experience, behavior and educational results. The indentifiable approaches are: Teaching the Exceptional and the Culturally different, Human relations, Single group studies, Multicultural education (cultural pluralism), Multicultural and social reconstruction. ${ }^{43}$ A multicultural education literacy approach would include the infusion of multicultural literacy in to the curriculum, ${ }^{44}$

In simple terms, multicultural education can be defined as education for/about cultural diversity in response to the demographic and cultural changes of a particular community's environment or even the world as a whole. ${ }^{45}$ Multicultural education is an educational model which carries an ideology that denies, and respects human dignity wherever it is and wherever it comes (economic, social, cultural, ethnic, linguistic, religious or religious, and state). ${ }^{46}$

Paulo Freire believes education is not an ivory tower that tries to stay away from social and cultural realities. According to him, education must be able to create an educated and educated society, not a society that only glorifies social prestige as a result of the wealth and prosperity it experiences ${ }^{47}$ Multicultural education is a response to the development of diversity in the school population, as demands equal rights for each group. Broadly speaking, multicultural education covers all students without differentiating groups such as gender, ethnicity, race, culture, social strata and religion.

Tilaar revealed that in multicultural education programs, the focus is no longer directed solely to racial, religious and cultural domain or mainstream groups. Such focus has been a pressure on intercultural education that emphasizes increasing understanding and tolerance of individuals who come from minority groups to the dominant mainstream culture, which in turn causes people from minority groups to be integrated into mainstream society. Multicultural education is actually an attitude of "care" and want to understand (difference), or "politics of recognition" political recognition of people from minority groups. ${ }^{48}$

Multicultural education is a way to teach diversity (teaching diversity). Multicultural

${ }^{43}$ Frederick L Yeo, Inner-City School, Multiculturalism and Teacher Education A. Proffesional Journey (New York and London: Garland Publishing, Inc, 1997), p. 116.

${ }^{44}$ Georgia Earnest Garcia and Arlette Ingram Willis, "Frame Works for Promoting Multicultural Literacies Moving Toward Eductional Justice," in Patricia Rugiano Schmidt and Althier M. Lazar, Recinseptualing Literacy in The New Age of Multiculturalis and Pluralism (Carlotte, NC: Information Age Publishing, Inc, 2016), p. 21.

${ }^{45}$ Ali Maksum, Pluralisme dan Multikulturalisme Paradigma Baru Pendidikan Agama Islam di Indonesia (Yogyakarta: Aditya Media, 2011), p. 90.

${ }^{46}$ Siti Julaiha, "Internalisasi Multikulturalisme dalam Pendidikan Islam," in Dinamika Ilmu, Vol. 14, No.1, Juni 2014, p. 113.

${ }^{47}$ Paulo Freire, Pendidikan Sebagai Praktek Pembebasan, tr. Alois A. Nugroho (Jakarta: Gramedia, 1984), p. 4.

${ }^{48}$ H.A.R Tilaar, Perubahan Sosial dan Pendidikan: Pengantar Pedagogik Transformatif untuk Indonesia (Jakarta: Grasindo, 2002), p. 59. 
education requires inter-relative ethical, intellectual, social, and pragmatic rationality: that is to teach the ideals of inclusivism, pluralism and mutual respect for all people, integrating the study of facts, history, culture, values, structures, perspectives, and the contribution of all groups into the curriculum so that they can build richer, more complex and accurate knowledge about the human condition in and across certain contexts of time, space and culture. ${ }^{49}$ Education broadly recognizes, respects, and accommodates diversity in gender, ethnicity, culture, race, social strata, religious schools, and religions. Multicultural educational goals to carry out people from stupidity, poverty, backwardness and injustice as a result of a hierarchical bottom-up partnership, domination-subordination, low-high, oppressiveoppressed in religious, ethnic, cultural, and gender relations. ${ }^{50}$ The ability to understand diversity according to Fuad Hasan as quoted by Muh. Idris must have begun to be formed through the national education system from the level of basic education and continue to the next level. ${ }^{51}$

Multicultural education looks at society more broadly. Based on the basic view that the attitude of "indiference" and "non-recognition" not only stems from racial structure inequality, but the multicultural education paradigm includes subjects regarding injustice, poverty, oppression and underdevelopment of minority groups in various fields: social, cultural, economics, education and so on. ${ }^{52}$ Such a paradigm will encourage the growth of studies on "ethnic studies" to later find its place in the education curriculum from the elementary level to tertiary institutions. The core purpose of the discussion on this subject is to achieve empowerment for minority groups and disadventaged. ${ }^{53}$

Broadly speaking, the multicultural education paradigm is expected to eliminate stereotypes, selfish, individualistic and exclusive attitudes and views among students. On the contrary, he is always conditioned to the growth of a comprehensive view of others, a view that recognizes that his existence cannot be separated or integrated with the surrounding environment whose reality consists of ethnic plurality, rationalism, religion, culture, and needs. ${ }^{54}$ Multicultural understanding by developing the nation's character in this activity can be implemented in learning by integrating curriculum content and the process of

${ }^{49}$ Zakiyuddin Baidhawi, Pendidikan Agama Berwawasan Multikultural (Jakarta: Penerbit Erlangga, 2005), p. 8

${ }^{50}$ Ety Murhayati and Yayah Nurhidah, "Multicultural Value in The Traditional Islamic Boarding School, Bina Insan Mulia (BIMA), Cirebon Indonesia," in Nadwa: Jurnal Pendidikan Islam, Vol. 13. No. 1 (2019), p. 168-169.

${ }^{51}$ Muh. Idris, Orientasi Pendidikan Islam (Yogyakarta: Penerbit Deepublish, 2020), h. 22; Muh. Idris, Pembaharuan Pemikiran Pendidikan Islam A. Malik Fadjar (Malang: UM Press, 2012), p. 39.

${ }^{52}$ Nur Achmad (ed.), Pluralitas Agama Kerukunan dalam Keragaman (Jakarta: Gramedia, 2001), p. 56.

${ }^{53}$ Ibid., p. 57.

${ }^{54}$ Choerul Mahfudz, Pendidikan Multikultural (Yogyakarta: Pustaka Pelajar, 2008), p. 276. 
implementing daily activities. In people's lives, moderate attitude, tolerance, and respect for the opinions of others. ${ }^{55}$

From the explanation above it can be seen that the concept of multicultural education Azyumardi Azra departs from the reality or condition of Indonesian society in order to strengthen (revitalize) the four pillars of national insight (Pancasila, NKRI, 1945 Constitution, and Unity in Diversity) and identity (Indonesian identity in Indonesian amidst the reality of the diversity of tribes, religions, races, genders, customs and social traditions, especially since the nation of Indonesia is now experiencing disorientation in various fields of life, even more complicated Indonesia contains tribal communities that are and live at different levels of culture or civilization. different, which contains cultural disparities and gaps. Some of our nation's people still live in pre-agrarian culture, then most in agrarian culture; some in industrial culture; and a small part have entered digital IT culture

The formation of Indonesia's multi-cultural society based on national insight cannot be taken for granted or trial and error. Instead it must be pursued in a systematic, programmatic, integrated and continuous manner, and needs to be accelerated (acceleration). One important strategy in accelerating it is multi-cultural education that is held through all educational institutions. ${ }^{56}$

Multicultural education seeks to offer solutions to anticipate conflicts caused by cultural differences. Multicultural-based education is seen as quite strategic for the process of social transformation. In addition to education being strategic enough to transfer knowledge, it is also able to cultivate critical power in students in analyzing social phenomena that occur around them. This strategy of instilling openness and respecting cultural pluralism democratically needs to be instilled early on through the process of education in school. With this kind of education we want students from elementary, middle to tertiary levels to grow in a world free of prejudice, bias and discrimination in any name - religion, gender, race, color, culture, class and so. Students who have strong character should always be democratic, pluralist and humanist.

\section{Conclusion}

The multicultural worldview in substance is not a common issue in Indonesia. The principle of Indonesia as a "Bhinneka Tunggal Ika" country if it reflects that even though Indonesia is multicultural, it is still integrated in the horizon which is the basis of the national insight. The formation of an Indonesian multicultural society based on national insight cannot be taken for granted or trial and error. Instead it must be pursued in a systematic,

${ }^{55}$ Subandi, et al., "Implementasi of Multicultural and Moderate Islamic Education at the Elementary Schools in Shaping the Nationalisme," in Tadris: Jurnal Keguruan dan Ilmu Tarbiyah, Vol. 4, No. 2, 2019, p. 249-250.

${ }^{56}$ Azyumardi Azra, "Revitalisasi Wawasan Kebangsaan." 
integrated and continuous way. One important strategy to accelerate it according to Azyumardi Azra is multicultural education which is held through all educational institutions, both formal and non-formal and even informal in the wider community.

Cultural realities and the latest developments in the social, political and cultural conditions of the nation which are full of social-political turmoil and conflict at various levels of society in Indonesia make multicultural education became necessary. Diversity or muliticulturalism is one of the main realities of society and culture in the past, especially in the present and future. But diversity should not be interpreted singly. Commitment to recognizing diversity as one of the main characteristics of a community does not mean dislocation, cultural relativism, social disruption or prolonged conflict in any community or society. Because at the same time there are also various symbols, values, structures and institutions in a common life that bind the various diversity.

In relation, the concept of multicultural education base on Azyumardi Azra thoughts is education for/about the cultural diversity of Indonesian society in the past and today which is undergoing demographic and socio-cultural changes. Multicultural education looks at society more broadly. Based on the basic view that indifference and non-recognition attitudes are rooted not only from racial structural inequalities, the multicultural education paradigm includes subjects regarding injustice, poverty, oppression and underdevelopment of minority groups in various fields; social, cultural, economic, educational, and others. This paradigm in turn encourages the growth of studies on ethnic studies, to then find its place in the education curriculum from the elementary level to tertiary education. The concept of multicultural education Azyumardi Azra departs from the reality or condition of Indonesian society in order to strengthen the four pillars of Indonesian nationhood and identity.

Azyumardi Azra's thought implies better research on ethnic studies, the result of which should be included in the education curriculum right from elementary to tertiary level. The multicultural education curriculum should include subjects such as tolerance, themes about ethno-cultural and religious differences, the dangers of discrimination, conflict resolution and mediation, human rights, democracy and plurality, universal humanity and other relevant subjects. Multicultural education is necessary at this time for the development of Indonesia which is expected to make an important contribution to the formation of unity in the midst of a truly actual diversity. This, in time, will strengthen the actualization of Pancasila as one of the main identities in the life of the nation and state.

\section{References}

Abdullah, M. Amin. Pendidikan Agama Era Multikultural-Multi Religius. Jakarta: PSAP, 2005. Achmad, Nur (ed.). Pluralitas Agama Kerukunan dalam Keragaman. Jakarta: Gramedia, 2001. 
Ariefuzzaman, Siti Napsiyah. "Prof. Dr. Azyumardi Azra, MA: Paradigma Baru Pendidikan Islam di Indonesia," in Chairul Fuad Yusuf dan Ahmad Syahid (ed.). Pemikir Pendidikan Islam: Biografi Sosial Intelektual. Jakarta: Pena Citasatria, 2007.

Arif, Mahmud. Pendidikan Islam Transformatif. Yogyakarta: LKiS, 2008.

Azra, Azyumardi. "Pendidikan Agama: Membangun Multikulturalisme Indonesia," in Zakiyuddin Baidhawi. Pendidikan Agama Berwawasan Multikultural. Jakarta: Penerbit Erlangga, 2003.

Azra, Azyumardi. "Revitalisasi Wawasan Kebangsaan: Pancasila, NKRI, UUD 1945 dan Bhinneka Tunggal Ika Pendekatan Pendidikan Multikultural." Makalah "Penguatan Nilai Kebangsaan Guna Merajut Kebhinnekaan dalam Rangka Ketahanan nasional" PPRA Lemhanas LVI 2017.

Azra, Azyumardi. "Revitalisasi Wawawasan Kebangsaan Melalui Pendidikan Multikultural," in Jurnal Ledalero, Vol. 18. No.2, 2019.

Azra, Azyumardi. Dari Harvard Hingga Mekkah. Jakarta: Penerbit Republika 2005.

Azra, Azyumardi. Jaringan Ulama Timur Tengah dan Kepulauan Nusantara Abad XVII dan XVIII: MelacakAkar-Akar Pembaruan Pemikiran Islam di Indonesia. Bandung: Mizan, 1994.

Azra, Azyumardi. Pendidikan Islam Tradisi dan Modernisasi di Tengah Tantangan Milenium III. Jakarta: Prenada Media Group, 2012.

Azra, Azyumardi. Pendidikan Islam Tradisi dan Modernisasi Menuju Milenium Baru. Ciputat: Logos Wacana Ilmu, 1999.

Baidhawi, Zakiyuddin. Pendidikan Agama Berwawasan Multikultural. Jakarta: Penerbit Erlangga, 2005.

Banks, James A. \& Cherry A. Mcgee Banks (ed.). Multicultural Education Issues and Perspective. The United States of America, 2010.

"Biografi Singkat Azyumardi Azra," in https://cakrawalazen.wordpress.com/2018/01/ 30/, accessed January 20, 2020.

Budianta, Melani. "Multikulturalisme dan Pendidikan Multikultural: Sebuah Gagasan Umum" in Tsaqafah, Vo. 1, No. 2, 2003.

Chadwick, Bruce A. et al. Metode Penelitian Ilmu Pengetahuan Sosial. Semarang: IKIP Press, 1991.

Fadjar, A. Malik. "Strategi Pengembangan Pendidikan Islam di Era Globalisasi," in M. Zainuddin and Muhammad In'am Esa (ed.). Horizon Baru Pengembangan Pendidikan Islam Upaya Merespon Dinamika Masyarakat Global. Malang: UIN Press, 2004.

Fanani, Ahmad Fuadi. Islam Mazhab Kritis Menggagas Keberagamaan Liberatif. Jakarta: Kompas, 2004.

Freire, Paulo. Pendidikan Sebagai Praktek Pembebasan, tr. Alois A. Nugroho Jakarta: Gramedia, 1984. 
Garcia, Georgia Earnest \& Arlette Ingram Willis. "Frame Works for Promoting Multicultural Literacies Moving Toward Eductional Justice" in Patricia Rugiano Schmidt and Althier M. Lazar. Recinseptualing Literacy in The New Age of Multiculturalis and Pluralism. Carlotte, NC: Information Age Publishing, Inc, 2016.

Idris, Muh. "Konsep Pendidikan Humanis dalam Pengembangan Pendidikan Islam," in Miqot Jurnal Ilmu-ilmu Keislaman, Vol.XXXVIII. No.2, 2014.

Idris, Muh. Orientasi Pendidikan Islam. Yogyakarta: Penerbit Deepublish, 2020.

Idris, Muh. Pembaharuan Pemikiran Pendidikan Islam A. Malik Fadjar. Malang: UM Press, 2012.

Idris, Muh., et al. "Peace Resolution in Education and Application on Information and Communication Technology" in International Journal of Advanced Science and Technology, Vol. 29, No. 6, 2020.

Irianto, Sulistyowati (ed.). Otonomi Perguruan Tinggi Suatu Keniscayaan. Jakarta: Yayasan Pustaka Obor Indonesia, 2003.

Julaiha, Siti. "Internalisasi Multikulturalisme dalam Pendidikan Islam," in Dinamika Ilmu, Vol. 14, No. 1, Juni 2014.

Ma'arif, Syamsul. Pendidikan Pluralisme di Indonesia. Yogyakarta: Logung Pustaka, 2005.

Mahfudz, Choerul. Pendidikan Multikultural. Yogyakarta: Pustaka Pelajar, 2008.

Maksum, Ali. Pluralisme dan Multikulturalisme Paradigma Baru Pendidikan Agama Islam di Indonesia, Yogyakarta: Aditya Media, 2011.

Marzuki, et al. "Multicultural Education in Salaf Pesantren and Prevention of Religious Radicalisme in Indonesia," in Cakrawala Pendidikan, Vol. 39, No. 1, Februari 2020.

Masamah, Ulfa \& Mualimul Huda. "Multicultural Education and The Natoionalistic Reality (Photograph The Role of Teachers in Building a Multicultural Awareness in Indonesia," in QIJIS: Qudus International Journal of Islamic Studies, Vol. 4, No. 1, Februari 2016.

Murhayati, Ety \& Yayah Nurhidah. "Multicultural Value in the Traditional Islamic Boarding School, Bina Insan Mulia (BIMA), Cirebon Indonesia," in Nadwa: Jurnal Pendidikan Islam, Vol. 13. No. 1, 2019.

Nandika, Dodi. Pendidikan di Indonesia di Tengah Gelombang Perubahan. Jakarta: Pustaka LP3ES Indonesia, 2007.

"Pendidikan Multikultural Membangun Kembali Indonesia Bhinneka Tunggal Ika," in https://wewenimas.wordpress.com/2011/03/30/, accessed January 20, 2020.

Raihani. "Islamic Education and the Multicultural Society: Description of Education for Cultural Diversity in Two Islamic Schools in Indonesia," in Jurnal JISCA Vol. 3 No. 2, 2014.

Ramly, Najmuddin. Membangun Pendidikan yang Memberdayakan dan Mencerahkan, Jakarta: Penerbit Grafindo Khazanah Ilmu, 2005.

Rosyada, Dede. "Pendidikan Multikultural di Indonesia Sebuah Pandangan Konsepsional," in Sosio Didaktika Social Science Education Journal, Vol.1 No.1 Juni 2014. 
MIQOT Vol. 44 No. 1 January-June 2020

Subandi, et al. "Implementasi of Multicultural and Moderate Islamic Education at the Elementary Schools in Shaping the Nationalisme," in Tadris: Jurnal Keguruan dan Ilmu Tarbiyah, Vol. 4, No. 2, 2019.

Sugiyono. Metode Penelitian Pendidikan Pendekatan Kuantitatif, Kualitatif, dan R\&D. Bandung: Alfabeta, 2011.

Tilaar, H.A.R. Perubahan Sosial dan Pendidikan: Pengantar Pedagogik Transformatif untuk Indonesia. Jakarta: Grasindo, 2002.

Tolchah, Moch. "The Relation Between Nusantara Islam and Islamic Education in Comtemporay Indonesia," in Al-Ulum, Vo. 16, No. 1, Juni 2016.

Yaqqin, M. Ainul. Pendidikan Multikultural Cross-Cultural Understanding Untuk Demokrasi dan Keadilan. Yogyakarta: Pilar Media, 2007.

Yeo, Frederick L. Inner-City School. Multiculturalism and Teacher Education A. Proffesional Journey. New York and London: Garland Publishing, Inc, 1997.

Zainuddin, M., (ed.). Memadu Sains dan Agama Menuju Universitas Islam Masa Depan. Malang: Bayu Media Publishing, 2004. 